\title{
Positive straight leg raising test secondary to conjoined lumbosacral nerve roots
}

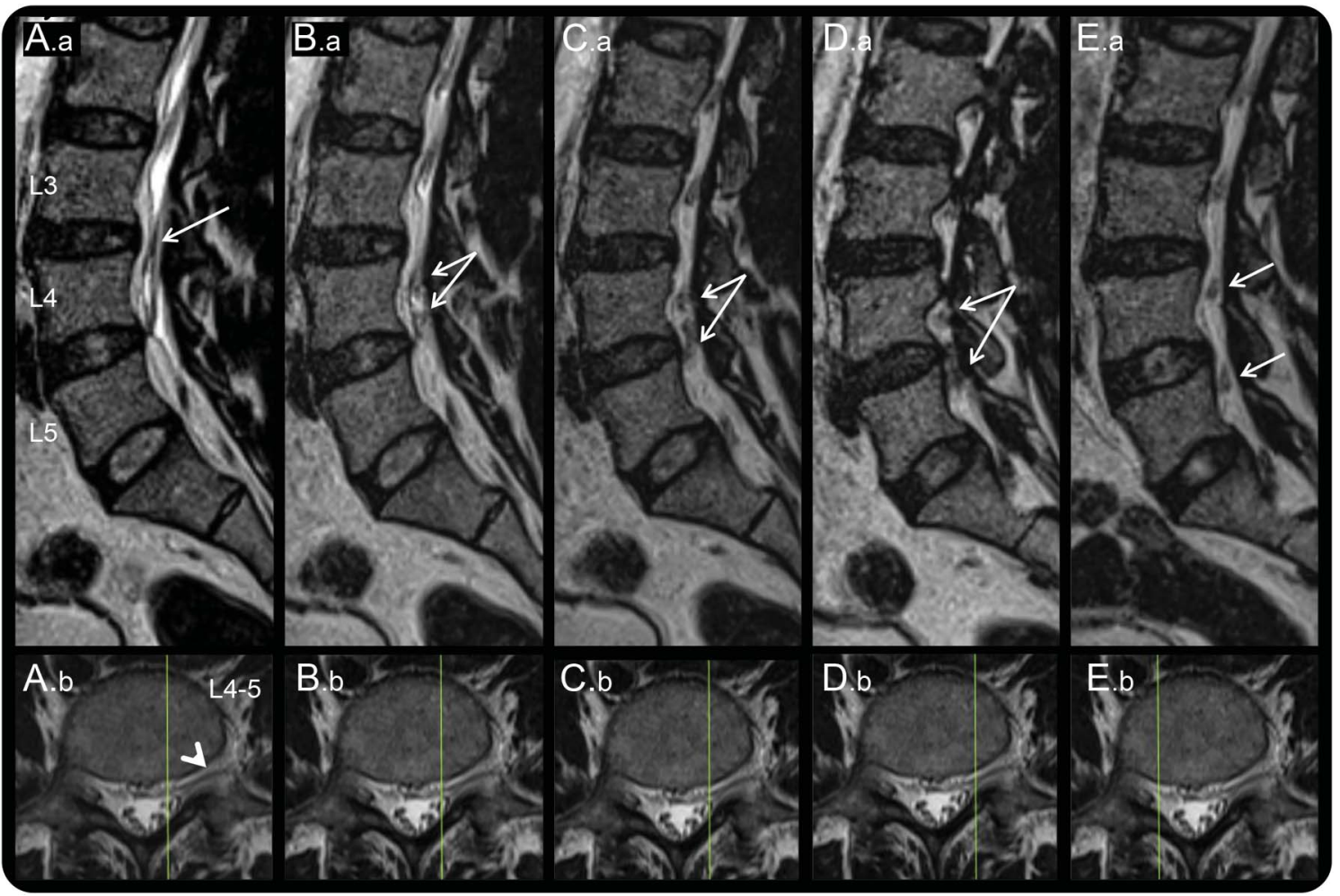

(A.a-D.a) Serial sagittal T2-weighted images of lumbar spine from midline to periphery showing single nerve root splitting into left $L 4$ and $L 5$ nerve roots (arrows). (E.a) Right paramedian sagittal section showing normal location of nerve roots (arrows). (A.b-E.b) Axial T2-weighted images at L4-5 disk level showing "parallel sign" (arrowhead).

A 53-year-old man presented with low backache and left lower limb pain of 3 months' duration, without radicular pain or lower limb weakness. Straight leg raising test was positive but the remainder of the neurologic examination was normal. His lumbosacral spine MRI revealed left L4 and L5 conjoined nerve roots (figure, A.a-D.a). The imaging was positive for sagittal "shoulder sign" (figure, A.a) and axial image "parallel sign" (figure, A.b), both favoring conjoined nerve roots. ${ }^{1}$ The absence of other neurologic signs with no imaging evidence of nerve root compression on the left suggests that the positive straight leg raising test was attributable to conjoined lumbosacral nerve roots. ${ }^{2}$

Kamble J. Harsha, MD, DM, Jain G. Panattil, MS, Mch

From the Departments of Neuroimageology and Interventional Neuroradiology (K.J.H.) and Neurosurgery (J.G.P.), Indo-American Hospital: Brain \& Spine Centre, Chemmankary, Vaikom, India.

Author contributions: Dr. Harsha: MRI evaluation, drafting and revising the manuscript. Dr. Panattil: examination of the patient, reviewing the manuscript.

Study funding: No targeted funding reported.

Disclosure: The authors report no disclosures relevant to the manuscript. Go to Neurology.org for full disclosures.

Correspondence to Dr. Harsha: kjharsha@gmail.com

1. Song SJ, Lee JW, Choi JY, et al. Imaging features suggestive of conjoined nerve root on routine axial MRI. Skeletal Radiol 2008; 37:133-138.

2. Lotan R, Al-Rashdi A, Yee A, Finkelstein J. Clinical features of conjoined lumbosacral nerve roots versus lumbar intervertebral disc herniations. Eur Spine J 2010;19:1094-1098. 


\section{Neurology}

\section{Positive straight leg raising test secondary to conjoined lumbosacral nerve roots}

Kamble J. Harsha and Jain G. Panattil

Neurology 2015;85;1913

DOI 10.1212/WNL.0000000000002148

This information is current as of November 23, 2015

\section{Updated Information \&} Services

References

Subspecialty Collections

Permissions \& Licensing

Reprints including high resolution figures, can be found at: http://n.neurology.org/content/85/21/1913.full

This article cites 2 articles, 0 of which you can access for free at: http://n.neurology.org/content/85/21/1913.full\#ref-list-1

This article, along with others on similar topics, appears in the following collection(s):

\section{All Pain}

http://n.neurology.org/cgi/collection/all_pain

All Spinal Cord

http://n.neurology.org/cgi/collection/all_spinal_cord

Diagnostic test assessment

http://n.neurology.org/cgi/collection/diagnostic_test_assessment_ Disc disease

http://n.neurology.org/cgi/collection/disc_disease

MRI

http://n.neurology.org/cgi/collection/mri

Information about reproducing this article in parts (figures,tables) or in its entirety can be found online at:

http://www.neurology.org/about/about_the_journal\#permissions

Information about ordering reprints can be found online:

http://n.neurology.org/subscribers/advertise

Neurology ${ }^{\circledR}$ is the official journal of the American Academy of Neurology. Published continuously since 1951, it is now a weekly with 48 issues per year. Copyright () 2015 American Academy of Neurology. All rights reserved. Print ISSN: 0028-3878. Online ISSN: 1526-632X.

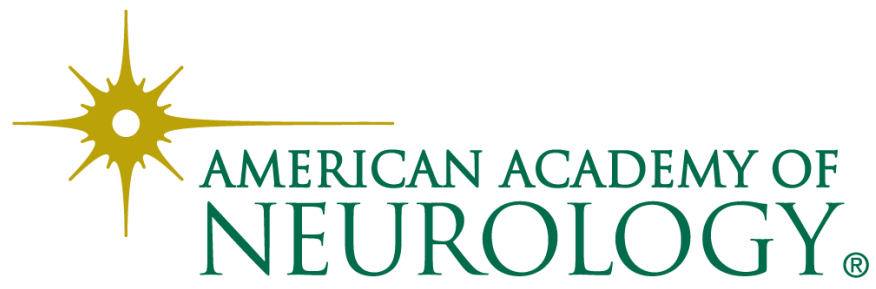

